\title{
ISLAMIC BANKS SERVICE INNOVATION QUALITY: CONCEPTUAL MODEL
}

\author{
Tahreem Noor Khan
}

\begin{abstract}
Islamic Banks Service Innovation Quality: Conceptual Model. Customer perspectives and satisfaction level are considered important for analysing the performance of Islamic bank service quality. Sufficient researches has been done to explore customer perception and satisfaction level with Islamic banking service quality, however there is lack of data to compare and find the similarity in understanding the main determinant attributes needed for Islamic banking service quality. The purpose of this paper is to describe and integrate the results of existing wealth of research on service quality in Islamic banks. After weighing up all the views from existing research, common findings, concerns will be discussed. This research did not find much of information or studies indicating toward innovation in Islamic banking service quality. Thus based on review of the literature this paper suggests main key attributes of service for Islamic banks (RIBA Service IQ). This research strongly asserts that sincere motivation, truthful intention, dynamic and practical service innovation of quality approaches can uplift Islamic financial brand.
\end{abstract}

Keywords: quality; service; Islamic banks; customer satisfaction; innovation

\begin{abstract}
Abstrak. Inovasi Kualitas Layanan Bank Syariab: Model Konseptual. Persepsi konsumen dan tingkat kepuasan merupakan elemen penting dalam menganalisis kinerja dari kualitas layanan bank syariah. Telah banyak penelitian yang membahas persepsi konsumen dan tingkat kepuasan terhadap kualitas layanan bank syariah, namun masih ada keterbatasan data untuk membandingkan dan menemukan keterkaitannya dengan faktor penentu utama yang dibutuhkan dalam kualitas layanan bank syariah. Tujuan dari artikel ini ialah untuk menggambarkan dan mengintegrasikan hasil-hasil penelitian yang ada mengenai kualitas layanan di bank syariah, kemudian mencari temuan umum untuk kemudian didiskusikan. Penelitian ini tidak menemukan banyak informasi mengenai kajian terkait innovasi kualitas layanan bank syariah. Oleh karenanya berdasarkan kajian kepustakaan yang dilakukan dalam kajian ini menyarankan atribut utama dalam kualitas layanan bank syariah ialah RIBA Service IQ. Kajian ini menekankan pentingnya motivate, intensi kepercayaan, dinamis, dan innovasi layanan merupakan beberapa hal yang dapat meningkatkan citra atau merek dari keuangan syariah.
\end{abstract}

Kata Kunci: kualitas; layanan; bank syariah; kepuasan konsumen; inovasi 


\section{Introduction}

Islamic banking emerged rapidly to fulfil the financial needs of Muslim consumers, by using different viable modes of Islamic financing. These tools of financing were designed to avoid, unjustified increase of money on money (ribā), risk-free return and high uncertainty (gharar). To offer Islamic finance products and services, the number of full-fledged Islamic bank branches has increased since 1985 . The industry then further expanded with the entrance of local and international conventional banks, which advertised their Islamic banking products heavily. At the present time of heightened competition, it has become more difficult for Islamic banks to differentiate themselves. It is believed that the competitors can quickly copy product and its sharia structure; however it is believed that only the quality of service can be often the differentiating factor between competing banks (Ryal and Knox, 2001; Zeithaml, Berry and Parasuraman, 1988; Ioanna, 2002). Wilson (2009) also stresses that while competing with conventional institutions, Islamic banks need differentiate their services through quality. Availability of products/ services of a higher level, and religious perspective can make Islamic banking easier to choose and can increase customer satisfaction and trust (Haque, et.al, 2009).

To check the penetration level in such intense competitive environment, different methods and techniques have been applied to measure customer satisfaction, knowledge, awareness, trust and level of quality (Aaker, 1996). Parasuraman, Zeithaml, and Berry (1993) proposed a specific list of service quality dimensions to determine the difference of customers' expectations and the actual level of service received: (1) Tangible: Equipment and appearance of staff. (2) Reliability: Ability to perform the promised service accurately (3) Responsiveness: Willingness to help customers, provide prompt service and apologies for any error or mistake (5) Assurance: Staff knowledge, courtesy and politeness of employee (6) Empathy: Satisfactory communication and understand individual customers need

In this respect, it is interesting to note that after almost thirty years of the Gaps Model (service quality model by Parasuraman, Zeithaml and Berry 1985, 1988) still researchers utilize original version or adapt with adjustments its scope and application. It is mainly used because of its ease of use and adaptability to different service sectors (Nyeck, et.al, 2002).

Existing literature also believe that Islamic banks' managers can use the CARTER model (Compliance, Assurance, Reliability, Tangibility, Empathy, and Responsiveness) for understanding customers' needs, and to improve Islamic bank service and performance (Othman and Lynn, 2001; Shahril, et.al, 2004). Available data established that there can be a direct, positive, significant and strong link between the effect of service quality on product quality awareness, trust and 
most importantly customer satisfaction/loyalty in Islamic banking (Noravida, 2015; Shiraj, et.al, 2014; Bashir, Naeem Akhter, et.al, 2011; Irwan, et.al, 2013; Rashid, et.al, 2014; Warsito, 2015; Hidayat, et.al, 2015). Customer service quality is highly significant on corporate image and highly significant on switching cost aswell (Naveed, et.al, 2014). If the service were not satisfactory customers would be would disappoint and might leave an organisation (Tang and Zairi, 1998; Karin and Ghauri, 2004). According to Fisk (1993), "The quality of service provided to a customer is one of the main links to customer satisfaction, and customer satisfaction leads to customer retention."

Customers will remain loyal to an organisation if the service value is greater than that expected from competitors (Zeithaml and Bitner, 1996). Innovation capability has a significant impact to attract the customer towards the organization (Naveed, et.al, 2014). In fact, the prerequisite of high-quality service may be a differentiation strategy in enhancing customer satisfaction (Muslim and Zaidi, 2008). In such harsh competitive global banking market and availability of products /services, Islamic banking has no choice but to focus on attracting, developing, and retaining customer satisfaction. It can be achieved if Islamic banking has good information about customer satisfaction (Muslim and Zaidi, 2008).

Literature indicates that most of the customers choose Islamic financial providers as a result of Islamic aspect and economic/quality services (Erol, et.al, 1990; Haron et al., 1994; Dusuki and Abdullah, 2007; Haque, et.al, 2009, Sehrish, 2011; Cheng, et.al, 2011; Salah, 2014; Sameena, 2014). In most cases, religious preference is high because of culture, environment, upbringing, Islamic knowledge and understanding toward religion. However Abdulkader identify moderate Muslims who give more priority to service quality and the time value of their savings (Abdul Kader, 1993). Not only Muslim, in Kuwait, conventional banks' users prefers Islamic banks because of better service (AlSultan, 1999).

Along with religious element, studies indicate that, indicates that, Islamic bank management perceived that their service delivery was unsatisfactory (Izah and Mazlina, 2009). In Pakistan bank managers also feels some lacking of service attitude by the Islamic banks might be some policy matters by the top management (Agha \& Ali, 2013). Wakhid and Soviyanti (2007), study also suggested that Islamic leader should lead in such case. Abed (2011) also suggested changes in some factors such as: Employee training and Management decision making, although these kinds of changes need more money and time, in long run it will lead to Customer Satisfaction. Banks should give much attention to issues perceived minor by them but considered as highly important for the depositors such as the dress code of female staff, promptness in giving responses, effective communication skills, and 
strict adherence to information about the bank CSR activities (Muhammad Abduh, 2011). The crucial areas that need the attention of the management were related to reliability and responsiveness (Izah and Mazlina, 2009).

Negative influence of 'Responsiveness' on customer satisfaction exist: rarely provides prompt services and customers have to wait longer hours to be facilitated, thus it then demands for the redesign of the existing communication network of the banks (Asif and Zaheer, 2014; Mubassher and Maryam, 2014). Faizan \& Zhou (2013) study suggests that Islamic banks can improve their service quality by improving their Internet facilities and online services. Indeed, sufficient knowledge in various Islamic banking instruments compounded with other relevant aspects such as ethics, professionalism in handling any transaction, duties and responsibilities will enhance productivity and smooth-running of Islamic banking (Noravida, 2015, Dusuki and Abdullah, 2006).

To retain customers, increase customer satisfaction and profitability, in such intense competition it is essential for Islamic bank management and leaders to integrate Service Quality Innovation into their planning and service. Islamic banks may require focusing on strategic choice and providing innovative products/services to gain competitive advantage (Muhammad Ali, 2015). Islamic banks need to have a clear understanding of their core capabilities in compare to their competitors, and how well Islamic bank work together with customers and internal and external experts (sharia scholars, academics, bank professionals, senior researchers) to deliver innovative products and services. They need to make sure roles, responsibilities and culture in the Islamic bank support Service Quality Innovation is having an effective metrics to measure and reward successful innovation.

\section{Methods}

The research design, guided by a Qualitative philosophy, inductive in nature. Based on extensive literature review methodology on existing body of knowledge regarding Islamic banks Service Quality. Most of the existing studies (empirical survey) emphasizing one or two country with reasonable customer sample, they set hypotheses to prove that service quality has linked with customer satisfaction and found that there is a direct positive relationship with service excellence as it leads to customer satisfaction and then change into customer loyalty (Rashid, et.al, 2014).

Each existing research has its purpose and findings, however this study believe that the impact of research will be more if we extract the common issues and findings of similar available researches (around 40) to understand the main attribute of service quality in Islamic banks in a greater perspective. This research 
made an attempt to collect existing researches between 2000- 2015 with regard to 'Islamic bank service quality' and 'Quality framework model Islamic bank' without restriction to any specific country.

Most of the existing studies used framework of the Service Quality Gap Model of Parasuraman with some modification with religious aspect. Academia seriously lack in-depth research or model thus this research study around 27 existing CATER Islamic banking service survey to identify the most common Highest and Lowest CATER suggested by literature which Islamic bank can focus on strategically to improve their service quality. Researcher believe innovation is possible in Islamic bank service but, some elements need to be focus: Mission and vision statements, HR practice and training, Service innovation regime and Effective Marketing and Measurement strategies

\section{Result and Discussion}

There is no specific current service innovation model/study for Islamic banks therefore based on existing research findings, proposing conceptual service innovation model for Islamic bank. Before proposing the model, a discussion of the above four points and the relevant literature review that led to the deduction of these points will be presented.

\section{Constant Reinforcement of element of Vision/Mission statements}

Grais and Pellegrini (2006) explore that selection of mission statements of Islamic financial institutions focus on two broad sets of objectives (compliance and service). Kahf (2004) believed Islamic banks can improved their service through the following: personalizing banking service, providing social objective products/ services, raising the professional level of employed service with customers, and strong concern in the investment department. Grais and Pellegrini (2006) said that to the provision of excellent services are services should provide to all community and promoting professional and qualities of management.

In the same line of approach, Nevine (2013) reviewed 8 Conventional banks and the 2 major Islamic banks in Egypt, and suggested that management should ensure that the banking environment should concentrate on fair and prompt service to their customers. Corporate Social Responsibility positively influences customer satisfaction toward banking service quality. Managers need to be convinced that social-welfare and profit maximization objectives need not be conflicting goals. Instead, commitment towards various social-welfare initiatives and programs could be used as a strategic marketing tool to enhance reputation 
and secure stakeholders commitment, which is beneficial and profitable for the business in the long run.

Almost all major Islamic banks emphasize on the same broad approach: unique products, fast, convenient service, technological innovation. Though it is understandable that mission statement in isolation cannot constitute an effective driver behind higher performance, it is recommended that the businesses should coupled these statements with well-motivated team to make sure that Islamic banks respond to the needs of their clientele much in line with their mission statements. A competent, knowledgeable seniors Islamic bank managers will prevents mission drift and actively plans the future, redefined on a regular basis in line with changing circumstances, Stick to culture and religious knitting, keeping the market led vision and mission central. It provides practical advice to management in key areas such as Islamic law, strategic planning, information technology etc. Failure to forge and communicate a coherent service quality strategy is a serious service quality gap. The implication here is that there should be an interdependent relationship between the mission statement and the practices of Islamic banks for the mission statement to translate into enhanced performance and give that entity a competitive advantage. Strategy is describe as a critical aspect and prerequisite for any sort of innovative activity, and believe without it innovation may be blind, directionless, or never occur (Rubalcaba et al. 2012; Stewart and Fenn, 2006).

In 2014, Jordan Dubai Islamic bank (JDIB) won the 'Best Innovative Bank' award by Global Finance Magazine, their mission statement focuses on: "To provide distinctive and innovative services emanating from the divine principles of Islam to build lasting and solid partnerships and to maximize benefits to all stakeholders". Thus JDIB banking philosophy is embodied in the bank's slogan "Solid Principles, Innovative Solutions.

It is worth mentioning that JDIB is the first Islamic Bank to utilize the innovative services including the Queuing System and introduced award winning products; such as Safwa (elite and affluent customers banking services within the framework of privacy, perfection and respect) and Kanzy (kids'saving account).

Similarly, in 2015, Noor Bank Named 'Most Innovative' Islamic Financial Institution by Global Finance Magazine. Noor Bank Mission is, "To be ranked among the top 100 most innovative companies in the world, by 2020".

As a result to fulfil mission component, Noor Bank support deployment of Innovative Mobile Wallet, it will enable users as to make secure and safe payments at many retail outlets within Dubai through their mobile phones - as an alternative to cash. Users will have an option to top up their Mobile Wallet using cash, or their existing credit cards, or direct bank account transfers, or by transferring funds from 
one wallet to another - allowing multiple channels. This will be the first application with a stored-value Mobile Wallet feature in the region.

\section{Develop Service innovative culture by investing in HR practice and training:}

Shahril, et.al (2004) raise that who should be involved and responsible for implementing service quality in Islamic banks: should it be the board of director, the general manager, mid- management, or all of them? (Shahril, et.al, 2004). For that Shahrani (2015) suggests that Islamic banks need to create feasible service quality programs and put into practice at all management and departmental level. Rice and Essam (2001) suggest that Islamic banks should use a case study approach (employee interviews, focus group surveys and observation) to check integration of top management, staff satisfaction, quality and innovation. However, this research believes, energy alignment is required from top to bottom level, no matter which hierarchy is responsible for developing service quality program.

Instilling a "culture" of customer service is highly dependent on the commitment and competence of the employees, however it involves a host of management and organizational processes such as staff recruitment, selection, training and teaming. Innovative mechanism should be developing at Islamic banks to build staff capacity, successor planning, and a mentorship programme, which rotates potential managerial staff around departments. It will give them exposure to get knowledge about religious implications at banks and operational side as well. Migrating to a service culture is possible in the presence of these satisfying factors it may also create positive, virtuous circles, reinforcing the bond between contact staff of Islamic banks and customers. Employees' care, willingness to help (responsiveness), accurate information and free of uncertainty were the most important factors in providing quality of service by Islamic banks to their customer satisfaction, trust and credibility of the bank (Irwan, 2013). Gronroos (1988, p 13) maintained that customers expect "immediate" and "active" corrective action when a service failure occurs. For taking corrective action, Islamic bank should begin to identify weak area and makeup for such weak aspect, such as most of the customers complained about shortage of staff. Islamic bank should realize and take initiative to increase the number of employees for speedy transaction specifically during rush days (e.g. Ramadan, Eid, Hajj). This can maintain the level of customer satisfaction (Ramdhani, et.al, 2011).

Islamic banks need to invest heavily in training and development of human resource, as it will improve customers handling and enhance image and reputation of the banks, which is the most major determinant for the customer satisfaction (Noravida, 2015). Islamic banks staff should receive training in the skills and 
capabilities required to deliver service excellence: interpersonal communication, sales techniques, customer care: identifying and resolving client difficulties, emotional smile campaigns, "personalized service" and "service recovery". Such service thinking and service mindset enhances the quality of Islamic banking staff which, in turn, will influence or attract more customers into choosing Islamic financing as their preferred choice (Abdel Kader, 2009). More qualified, experts and knowledge-based work forces are needed for this purpose to be absorbed into this industry. Presence of such qualified experts and knowledge-based work forces will help to promote greater innovation especially in dealing with Islamic financial products (Abdul Ghafoor and Maliha, 2014).

Staff motivation and energy alignment. In many Islamic organizations leader does not want to listen to any critics and most of their task is just depend on verbal communication, it effect the relationship between leader and subordinate (Tanjung and Bahri, 2005). Noravida, (2015) recommended establishing a motivating system for Islamic bank employees as well. Adequate levels of autonomy, allowing employees to set objectives, well-designed incentive schemes based on staff performance, and ensure improved service delivery. Internal communication and inexpensive corporate notice boards can be used to encourage staff suggestions. For this very reason employee energy alignment and back office process improvements are very innovative endeavours, which demand sustainability, discipline and forethought.

\section{Service innovation regime in Islamic banks: Customer input}

Islamic banks should not take for granted the expectation of their customers by assuming that they are prompted to deal with Islamic banks solely based on their religious consciousness. Rather, Islamic bank management must measure the overall customer's satisfaction and understand the nature of service quality and customer value and how these features promote in satisfying customers (Abdel Kader, 2009; Shahrani, 2015). Customers have a different preference in every step of their transaction and decision process (Pepper, 1999). Different consumers have different criteria for using bank products and services, one may choose a bank for religious reason only whereas other consider Islamic banks because of convenient ATM locations, accessibility of the branch, sufficient parking or low charges (Salih, et.al, 2014; Abdel Kader, 2009). Recognizing those customers' individual differences, financial services need to be delivered that are variable, frequent, convenient, affordable, and sustainable.

A survey revealed that respondents in Saudi Arabia are dissatisfied or neutral position with regard to quality services. There is no department responsible for quality measure and control in organization, therefore study suggest that here is a 
need to utilize quality knowledge and practice at both operational and managerial level (AlShahrani, 2015). Any customers' complaints or disappointments upon Islamic bank's service quality must be treated wisely and carefully in order to retain existing customers and prevent them from switching to other banks (Muhammad Abduh et al., 2014). Often customers complain that all customers are not treated equally. They have to wait a long time to have a service. According to them valued and loyal customers always get extra facility and customized services from officers where normal customer do not. Systematic monitoring of complaint data should lead to identification of critical service encounters and potential failure points. Input from employees to this process is vital, as they can contribute to identification of the causes of failures and resulting customer dissatisfaction (Muhammad Abduh et.al, 2014). It will help in innovating the specialized services according to the needs and demands of the customers. In this regard, the financial institutions must focus in terms of end result of their service quality innovations (Mubassher and Maryam, 2014).

Not to ignore demographic aspect: Impact of service quality factor on customer satisfaction among the customer is depends upon the demographic profile of the customers. Frequent surveys, specifically demographical approach could be conducted to obtain the data from the different customers regarding their perceptions, expectations and recommendations to improve the service quality (Mubassher and Maryam, 2014). For example, the degree of influence of the service quality factors on customer's satisfaction is higher among the male, mature and highly educated customers (Norma, 2012). Among non-Muslims, the X-Generation has a more favourable perception towards Islamic Banking than Baby Boomers (Loo, 2010).

The findings of Ahmad et al. (2010) suggested that bank managers should consider the demographic characteristics of their customers in order to take quality initiatives to improve their products. The findings provide a guideline to Islamic banks regarding meeting the expectations of male and female customers according to their specific requirements. Bank managers of both Islamic and conventional banks should take innovation on quality to improve their banking products and service by considering demographic characteristics of the customers (Shiraj, et.al, 2014).

Similarly Akram and Parves (2015), insist to conduct research about how demographic variables including income, gender, religion, age, and profession affect Islamic banking service quality perceptions? Many of the previous researches on this construct have been done in developed countries Mubasher and Maryam (2014) conducted this research study in a developing country where the concept of customer service and service quality is entirely different from developed 
countries on environmental grounds. Islamic banks need to be aware of another categorization of customer based on Taufeeq (Ability) and Hidayah (guidance). Research identified four types: "Sharia Loyalists" (Taufeeq+ Hidayah), "floating market" (taufeeq + no hidayah) or "market trend follower" (hidayah + without taufeeq) (Adnan, et.al, 2013).

Untangle research regarding Service innovation regime: Islamic banks customer service measures needs urgent improvement in order to ultimate survival in the banking sector (Agha \& Ali, 2013). Response rates for surveys of service quality and satisfaction "are declining" because they are often conducted with "a research mentality" research for the sake of research and do not adequately address the informational role or re-involve customers in providing on-going feedback to banking services. In such dire need, Islamic banks can establish an innovation incubator lab to drive improvement in products, services, and processes. External partnerships with academia and internal train dedicated innovation research teams can carry out customer-focused research to expand the department research ability. New ways of collecting data such as Islamic banking Service Quality "Idea contest", "brainstorming session with customers" and "mystery-shopping" can establish. Conducting a global competitor review on innovative practices in Islamic financial services can inspire idea generation. If Islamic banks adding new services, measure the return on that specific innovation. Efficiency in service innovation has to be appreciated. On the other hand, Islamic banks can share their experiences so their practical solution can become theory on academic grounds. Learning from academic to practical and vice versa can be proactive if the collaboration happens.

\section{Effective Marketing and Measurement strategies}

Shiraj, et.al. (2014) concluded that there is a positive and greater relationship between service quality and customer satisfaction in Islamic banks. However, in some cases, it is found that customers have limited knowledge in relation to Islamic banking products in Pakistan (Sehrish Rustam, 2011), Brunei (Bashir, 2013), and Kuwait Finance House (Kamal, et.al, 2013). This is due to the reason that Islamic banks have not done enough marketing their products and services. This requires more efforts from the bank's management to familiarize its customers with all its existing products and services as well as introducing new products (Kamal, et.al, 2013).

One of the main selection criteria of Islamic banking in Pakistan is: mass media advertising, along with responsive attitude of the bank staff (Abdul Ghafoor and Maliha, 2014). Some literature suggests that Islamic banks should pursue an aggressive customer awareness campaign about Islamic banking products and their benefits to the customers (Gambo, 2013). Whereas, other literature stresses Islamic 
banks may be required to do counselling, effective promotion to attract existing and potential target market and focus on strategic choice in providing products and services which are more innovative in order to gain competitive advantage (Muslim and Zaidi, 2008; Shiraj, et.al, 2014). Proper marketing and promotion of Islamic financial services will improve customer's satisfaction and reputation of Islamic banks (Abdul Ghafoor and Maliha, 2014).

The impact of service quality gaps on strategy formulation and implementation makes it increasingly important for the top management to realize. Lack of staff knowledge in the basic principles of Total Quality Management, work pressure and tight deadline, poorly defined indicators/too many indicators are decisive factors that affect negatively on growth and success of Islamic banks (Haque, et.al, 2014). Identification of key internal performance indicators, standard working procedures, organizational structures, redesign the business function and processes can serve as a measure of the effectiveness of the performance of the organization (Lubis, 2015; Mubassher and Maryam, 2014). For continuous improvement and adopting service quality effectively in Islamic banking management requires a clear understanding of what service quality means to their customers. Customer's may be more concerned towards other aspects of services, so prime objective of the business strategy of Islamic banks should be to use effective diagnostic tool to understand and determine premium service quality factors that enhance the customer perceived value, satisfaction and loyalty (Mubassher and Maryam, 2014).

Successful banks strategies: Literature suggests that Islamic banks may find it useful to observe the practices of successful banks so as to design their programs for enhancing the quality of their services (Shahrani, 2015). Interior benchmarking: Another suggestion to retain existing customers and attract more new customers was an interior benchmarking system, it can establish based on the results obtained (Noravida, 2015). Whichever franchise of Islamic banks that acquire high customer satisfaction should become a benchmark to be exampled by other branches of the bank and vice versa (Noravida, 2015). Train Islamic banks employees based on service quality measurement: Islamic banks should train their employees on the application of service quality measurement techniques. Service quality gaps affect service delivery; so departmental managers must detect and eliminate them as early as possible in any service operation. However, Islamic bank employees will not appreciate service quality measurement techniques if it has not led to increased job satisfaction, reduction of job process, and limited creativity.

Usages of latest technology should be increased and employee should be skilled in operating that technology. Without accessibility to data, makes the process impractical, and likely to be underutilized. The information needs to be 
updated due to customer needs and expectations change over time. To enhance the quality of service and its impact on the management, Saleh (2005) included 'Data Measurement, Analysis and Improvement' and 'Quality Practice Tools and Methodologies' in a model along with eight main elements: first, Management Leadership and Commitment. Second, Islamic Bank Strategic direction, including vision, mission. Third, Customer Focus as a Driving Force. Fourth, Core Business through Sharia Principles and Compliance. Fifth, Quality Practice Tools and Methodologies. Sixth, Bottom-up Contribution (through employees). Seventh, Competitive Infrastructure. Eight, Data Measurement, Analysis and Improvement

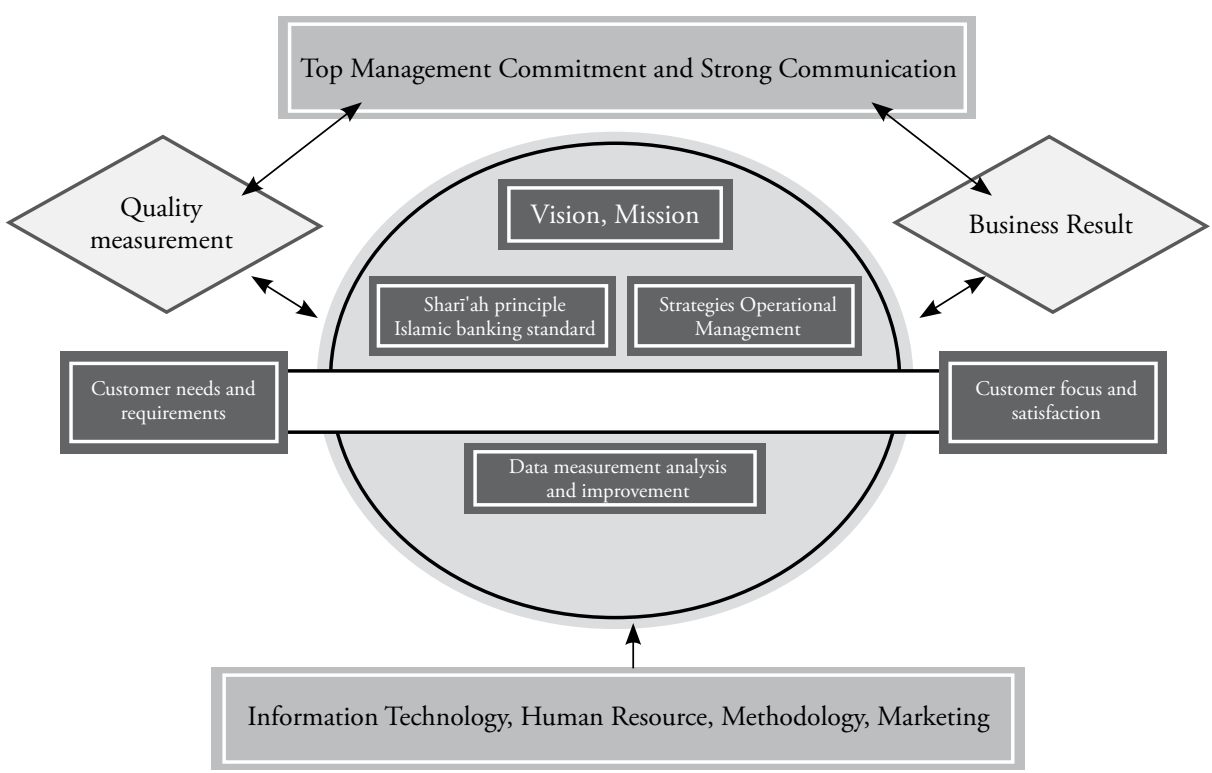

Figure 1-Islamic Banks Quality Monitoring (Saleh, 2005)

\section{Findings Islamic Banks Service Quality Dimensions}

Due to the pervading role of services, this research believes that service quality has no boundary or end point but can always be improved. Literature review findings also confirmed that service quality is one of the critical success factors that can effect customer satisfaction and loyalty. It is noticed_from the literature analysis that for Islamic bank customers, Religious factors considered as the main motivation in bank selection. To investigate religious aspect, CARTER model added Compliance dimension. Apart from religious factor, Responsiveness and Reliability dimensions are significant factor for Islamic banks customers. Responsiveness (timely reaction towards the customers' needs) is a crucial determinant of service quality, and the 
lack of this dimension can have, both negative and positive satisfaction element. Predominantly another most important dimension in Islamic banking service quality is Reliability, which relates to process quality, it evaluate whether expected standards and promises are deliver accordingly. Assurance and Tangibility can be addressed as the quality of social interactions and stresses personal attention between the customers and Islamic banks. According to table below Empathy is not a key aspect of Islamic banking service quality.

\section{Complexity of service quality evaluations}

To understand the key dimensions of service quality in Islamic banks and measuring the gap between customer expectations and experiences as a determinant of satisfaction, most of the above recent studies used framework of the Service Quality Gap Model of Parasuraman with some modification. It is hard to recognize that whether Islamic bank customers are not satisfied with the level of service or by its randomness in approach? Does inconsistency of one dimension (e.g. tangibility) have an effect on others? Does customer will leave bank, if Islamic bank interior is very fancy, attractive and grand but the staff service is impolite? Or Islamic bank is responding to customer queries but lack connectivity with customer emotions (lack of empathy), in that case customer will leave the bank? What if Islamic bank customers are not using Internet banking service, but perception about Internet banking is positive. Statements about courteous and reliable staff are meaningless if the customer perceives that he/she did not receive the credit card or other request.

Thus SERVQUAL deals with individual dimension without connecting with other dimensions thus narrow in scope. In this case it cannot provide the complete picture of service quality innovation in Islamic banking. First, Output of a service is hard to measure. The idea of prediction assumes that service quality deals with behavioral intentions, though every individual think, behave, and act in different way (Cronin, Brady, and Hult, 2000). Difference, which comes in at the level of delivery of service due the difference in human behaviour of those offering services and the consumer. No doubts expectations are likely to change over time and expectations involve subjectivity. It occurs when frontline staffs at bank offers assistance to one customer at the counter, that same person cannot offer exactly the same thing to the next customer because of differences in behaviours and query. This is why it is difficult to determine the quality and level of service provided since consumers queries and staff are different at every branch (Beamish and Ashford, 2007,). SERVQUAL does not enable to identify the difficulties, which are associated with outcomes of the service encounter as it focuses on the process of service delivery (Buttle, 1996). Second, unstable dimension, vague statements 
and lengthy customer's survey. Along with gap score issue with SERVQUAL instrument, another extensive criticism is related to use of improper wordings and unstable dimension (Cronin and Taylor, 1994; Jiang et al, 2002; Babakus and Boiler, 1992). Fawzan (2005) survey used (SB accounting system is good) which can be unclear statement to check with customer, how does customer knows about Islamic bank accounting, whether it is good? Similar context in sentences are found in Tangibility (SB layout nicely done) and Accessibility (moving inside SB is easy) such statements can be subjective. Differences exist in Islamic bank surveys used for measuring service quality, Muslim and Zaidi (2008) stated about banking hours in Tangibility whereas other research adds the similar statement in Accessibility. Buttle (1996) indicate that completing the SERVQUAL questionnaire is a lengthy process (questionnaire one section measures 22 expectations questions and then another section measure the perceptions with respect to the same 22 questions), and that the length of the questionnaire could lead to confusion. This research believes that measuring expectations is unnecessary, as every individual will have idealistic approach. And there will always be a gap in expected and actual service.

Third, Lack of service innovation quality models for Islamic banks. Wealth of research investigated the aspect of Islamic banking service, but no concrete suggestions are there to improve Islamic banking service innovation. Most of the surveys are investigating normal statements about customer service, trust/reliability factor, branch location and hours; there is not much to know what is missing in the key services. There is a possibility if same set of questions asked in negative statements (service is delayed or transaction occur with errors). Fourth, Sample size should be diverse: Most of the current service quality Islamic bank researches conducted data from one country or one bank; it will be more exploratory if comparison between different Islamic banks and countries will be analysed. Fifth, analyse the impact of service quality researches: it should be analyse whether the "Islamic bank service quality researches are conducting for the sake of research" or these academic research findings have an impact in improving Islamic banking service quality. Sixth, More dimensions are required: serious other factors need to incorporate such as, customers preference in using mobile applications, social networks and internet bank or strategic social responsibility factor can be included in dimensions: how important is social responsibility dimension compared to the other dimensions in the evaluation of service quality. Seventh, does survey talks about customer categories. Literature identifies two types of customers; The first group: strictly follow and stick to the religion "Sharia Loyalists" "and wanted to be with Islamic banking at any cost, second group moderate Muslims who give more priority to service quality and the time value of their savings, floating market" 
or "market trend follower (Abdul Kader, 1993; Adnan, et.al, 2013). Thus, Islamic banks need to be aware of such customer categories but in term of service quality survey one format is used for both categories.

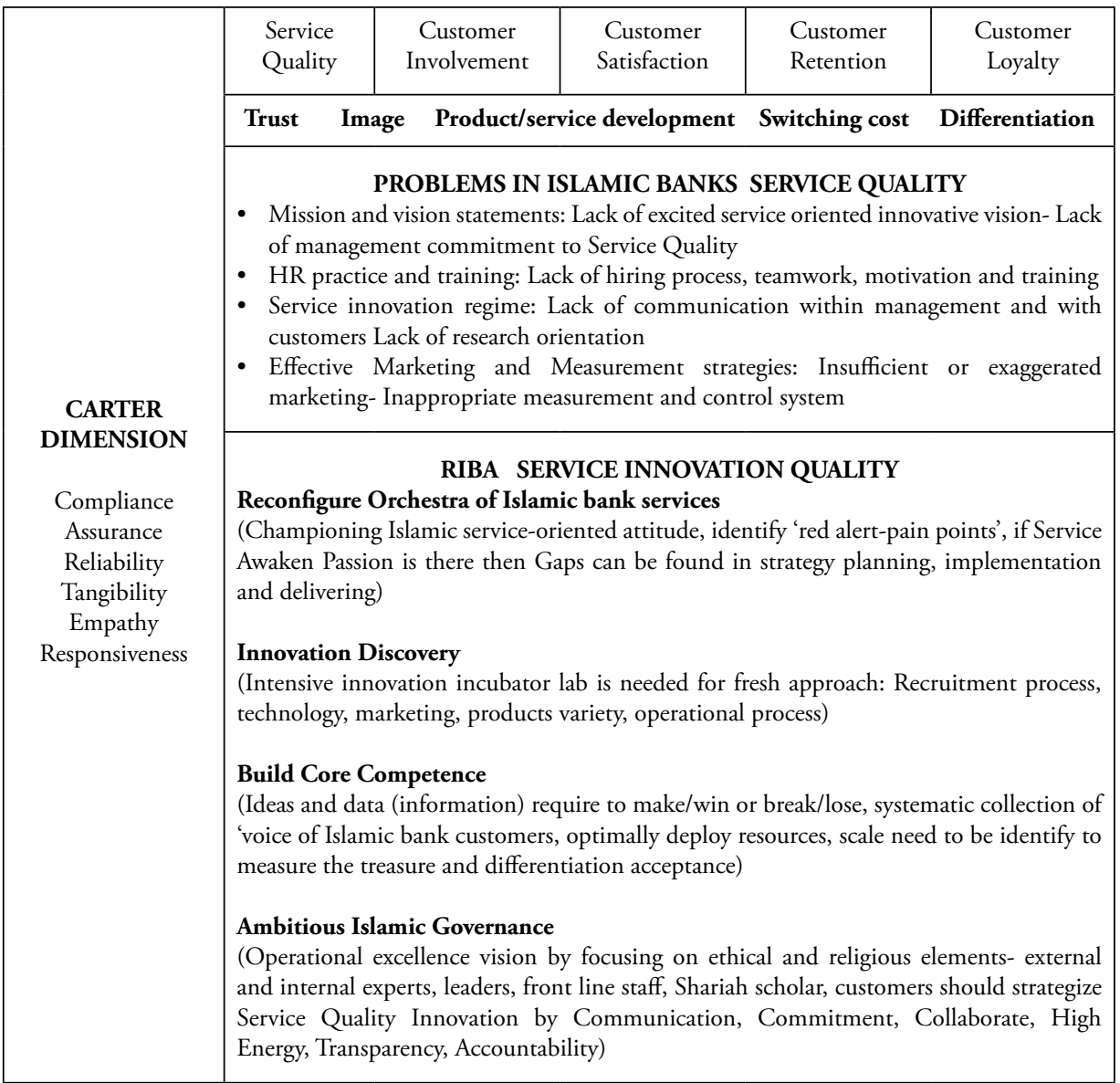

Along with CARTER scale, to master the intricacies, Islamic banks need to make a serious attempt to bring newness, fresh insight in every dimension of their service quality process. The connectivity of service quality with satisfaction and loyalty will remain a key problem if concern areas of management and services are not identified.

To deliver 'above and beyond', this research propose "RIBA Service IQ" in which Islamic banks should emphasis in building customer trust by offering what Islamic bank promise, by reconfiguring orchestra of Islamic bank services, discovery innovation at all organizational level, build core competence and by having Islamic management and governance. 


\section{Conclusion}

Service quality and customer satisfaction are highly correlated, and it further lead to customer retention. Thus interaction between customers and Islamic banks should be on respectful and acceptable terms by balancing between outcome of service (interaction with customer and staff); and service delivery process (comply with standards). Islamic banks need to adopt, integrated service framework to enhance internal coordination, planning, and implementation, which covers the strategy focus, employee, tools, technology and working process. On the basis of above articles, we find there is not much research done about the initiatives taken by Islamic banks for service quality innovation, most of the Islamic banking researches use CARTER service quality dimension (introduced 30 years back). All elements of CARTER are important as they are connected to each other: for example Responsiveness factor should have empathy element to make service more valuable. Similarly, Compliance factor is a major dimension to enhance Credibility and Assurance factor.

This research believes that overall, there is no 'one best way' to apply and measure performance of service quality models in Islamic banking sector. Despite the importance of service quality models assign to customer satisfaction discussed and examined in some worthy literatures of Islamic bank above, this research believes that without proper 'service direction and guidance' the benefits to organizations will be difficult to realise in practice. Islamic bank need 'correctors' for service innovation gaps, information is required for that. They should not use 'ready to go' idea instead they should find 'block buster idea' which can give them competitive advantage. Furthermore, by incorporating right measurement tool and transparency in governance element continuous improvement in delivering quality service is possible.

The uniqueness of this research is, it identifies the service quality dimensions which are found in existing literature related to Islamic bank context and suggested conceptual framework to enhance the service innovation quality aspect. Further research and case study can be done to compare the attributes of service quality innovation in Islamic banks. Call for a new direction in Islamic bank service innovation quality research can assist in alleviating the current block and stalemate.

\section{References}

Aaker, D. (1996). Building Strong Brands. New York: The Free Press.

Abduh, M. \& A.A.M. Othman. (2014). Service Quality Evaluation of Islamic Banks in UAE: An Importance-Performance Analysis Approach. Journal of Islamic Economics, Banking and Finance, Vol. 10 No. 2: 111-120. 
Abduh, M. (2011). Islamic Banking Service Quality and Withdrawal Risk: The Indonesian Experience. International Journal of Excellence in Islamic Banking and Finance. Vol. 1. No 2: 121-130.

Abdul Ghafoor, A. \& A. Maliha. (2014). Consumer Behaviour toward Islamic Banking in Pakistan. European Journal of Accounting Auditing and Finance Research. Vol. 2 (9): 42-65.

Abdel Kader, A. \& K. Norizan. (2009). Measuring perceived service quality in Qatari Islamic banks. International Business and Entrepreneurship Development. Vol. 4 (1): 71-80.

Adnan, A.A, Noor, et.al. (2013). Bank Choice Behaviour among Malaysian Muslims: A Qualitative Approach. International Research Journal of Social Sciences. Vol. 3 (2): 1-8.

Agha, T.I. \& A. Ali. (2013). Assessing Service Attitude: Service Quality Measures Taken by Islamic Banks in Pakistan. IOSR Journal of Business and Management. Vol. 8 (1): 61-68.

Akram, Al-Jazzazi \& S. Parves. (2015). Banking Service Quality in the Middle Eastern and GCC Countries: Understanding the Future Research Directions. Asian Journal of Business Research. Special issue: 71-80.

Asif, A. \& A. Zaheer. (2014). Service Quality Dimensions of Islamic Banks: A Scale Development Approach. Global Journal of Management and Business Research: Administration and Management. Vol. 14. No. 5: 411-420.

Babakus \& G.W. Boller. (1992). An empirical assessment of the SERVQUAL scales Journal of Business Research. Vol. 24. No.3: 253-68.

Bashir, M.S. (2013). Analysis of Customer Satisfaction with the Islamic Banking Sector: Case of Brunei Darussalam. Asian Journal of Business and Management Sciences. Vol. 2 No. 10: 38-50.

Berry, L \& P. Zeithmal. (1991). Marketing Services: Competing through Quality. New York: Prentice Hall.

Berry, L \& P. Zeithamal. (1993). Building a New Academic Field-The Case of Services Marketing. Journal of Retailing Vol. 69: 13-69.

Buttle, F. (1996). Unserviceable Concepts in Service Marketing, The Quarterly Review of Marketing Vol.11 No.3: 8- 14.

Cheng, W.H. et.al. (2011). Bank Selection Criteria and Service Quality of Islamic Banking: A Comparison between Muslim and Non-Muslim Students and its effect on Student Satisfaction. Jurnal Ekonom, Vol 14. No 3: 181-190.

Dusuki, A.W. \& N.I. Abdullah. (2006). The Ideal of Islamic Banking: Chasing a Mirage? INCEIF Islamic Banking and Finance Educational Colloquium, Bank Negara Malaysia, Kuala Lumpur. 3 Apr. 
Dusuki, A.W. \& N.I. Abdullah. (2007). Why do Malaysian Customers Patronize Islamic Banks? International Journal of Bank Marketing Vol. 25. No. 3: 142160.

Erol, C. et.al. (1990). Conventional and Islamic Bank: Patronage Behavior of Jordanian Customers. International Journal of Bank Marketing Vol. 8: 25-35.

Faizan, A. \& Y. Zhou. (2013). An Assessment of the Perceived Service Quality: Comparison of Islamic and Conventional Banks at Pakistan. International Journal of Innovation and Business Strategy. Vol. 2: 121-130.

Gambo, M. (2013). Customer Perception of the Effectiveness of Service Quality Delivery of Islamic Banks in Nigeria: An Evaluation of Jaiz Bank. Journal of Marketing and Consumer Research. Vol.1: 51-60

Grais, W. \& M. Pellegrini. (2006). Corporate Governance and Shari'ah Compliance in Institutions offering Islamic Financial Services. Policy Research Working Paper 4054. Washington: World Bank.

Grais, W \& M. Pellegrini. (2006). Corporate Governance in Institutions Offering Islamic Financial Services Issues and Options. Working Paper Ser. 4052. Washington: World Bank Policy Research.

Haque, A. et.al. (2009). Factor Influences Selection of Islamic Banking: A Study on Malaysian Customer Preferences. American Journal of Applied Sciences. Vol. 6 (5): $922-928$

Haque, A. et.al. (2014). Total Quality Management Practices in the Islamic Banking Industry: Comparison between Bangladesh and Malaysian Islamic Bank. International Journal of Ethics in Social Sciences. Vol. 2 No. 1: 6-16.

Haron, S. et.al. (1994). Bank Patronage Factors of Muslim and Non-Muslim Customers. International Journal of Bank Marketing Vol. 12. No.1: 32-40.

Hidayat, R. et.al. (2015). Effects of Service Quality, Customer Trust and Customer Religious Commitment on Customers Satisfaction and Loyalty of Islamic Banks in West Java. Al-Iqtishad: Jurnal Ilmu Ekonomi Syariah (Journal of Islamic Economics). Vol. 7 (2): 151-164.

Ioanna, P.D. (2002). The Role of Employee Development in Customer Relations: The Case of UK Retail Banks. Corporate Communication Vol. 7 No.1: 62-77.

Irwan, M. et.al. (2013). Islamic Bank Service Quality and Trust: Study on Islamic Bank in Makassar Indonesia. International Journal of Business and Management; Vol. 8 (5): 411-420.

Izah, M.T. and A.B.N. Mazlina. Islamic Banking Operations: Preparing the Fit for Internationalization. Journal of Islamic Economics, Banking and Finance, Vol. 5 (3): 51-60.

Jiang, J.J. et.al. (2002). Measuring information system service quality: SERVQUAL from the other side. MIS Quarterly, Vol. 26 No.2: 145-166. 
Kahf, Monzer. (2004). Success Factors of Islamic Banks. Brunei Symposium on Islamic Banking and Finance, Brunei. Jan.

Kamal, N. et.al. (2013). Customers Awareness and Satisfaction of Islamic Banking Products and Services: Evidence from the Kuwait Finance House. International Journal of Marketing Studies; Vol. 5: 6-20.

Loo, M. (2010). Attitudes and Perceptions towards Islamic Banking among Muslims and Non-Muslims in Malaysia: Implications for Marketing to Baby Boomers and X-Generation. International Journal of Arts and Sciences. Vol. 3 (13): 453485 .

Muslim, Amin., and Zaidi Isa. (2008). An examination of the relationship between service quality perception and customer satisfaction A SEM approach towards Malaysian Islamic banking. International Journal of Islamic and Middle Eastern Finance and Management. Vol. 1 No. 3, pp. 191-209.

Naeem Akhtar, M. et.al. (2011). Relationship Between Customer Satisfaction and Service Quality of Islamic Banks. World Applied Sciences Journal Vol.13 (3): 453-459.

Naveed, A. et.al. (2014). Managing Service Quality Customer Loyalty and The Role of Relationship Length. International Letters of Social and Humanistic Sciences Vol. 38: 70-81.

Nevine, Sobhy Abdel Megeid. (2013).The Impact of Service Quality on Financial Performance and Corporate Social Responsibility: Conventional Versus Islamic Banks in Egypt. International Journal of Finance and Accounting. Vol.2 No.3, pp.150-163.

Norma, Md. Saad. (2012). Comparative Analysis of Customer Satisfaction on Islamic and Conventional Banks in Malaysia. Asian Social Science Vol. 8, No. 1: 41-50.

Nyeck, S. et.al (2002). 10 years of service quality measurement: reviewing the use of the SERVQUAL instrument. Cuadernos de Difusion: pp: 101-107.

Othman, A. \& O. Lynn. (2001). The Multidimensionality of Carter Model to Measure Service Quality in Islamic Banks: A Case Study in Kuwait Finance House. International Journal of Islamic Financial Services Vol. 3 (4): 311-320.

Parasuraman, et.al. (1985). A Conceptual Model of Service Quality and its Implications for Future Research. Journal of Marketing Vol. 49. No.4: 41-50.

Ramdhani, M.A. et.al. (2011). The Influence of Service Quality Toward Customer Satisfaction Of Islamic Sharia Bank. Australian Journal of Basic and Applied Sciences, Vol.5 (9): 1099-1104.

Rashid, S. et.al. (2014). Impact of Service Quality on Customer Loyalty in Islamic Banking Sector of Pakistan: A Mediating Role of Customer Satisfaction. Journal. Basic. Applied. Science. Research, Vol. 4 (2): 135-143. 
Rice, G. \& M. Essam. (2001). Integrating Quality Management, Creativity and Innovation in Islamic Banks. Lariba 8th Annual International Conference, Paper presented at the American Finance House, Pasadena, 16 June.

Rubalcaba, L. et.al. (2012). Shaping, Organizing, and Rethinking Service Innovation: a Multidimensional Framework. Journal of Service Management, Vol. 23 (5): 696-715.

Saleh, Khalid Ahmed. (2005). Quality in Islamic Banking Sectors Model and Framework Case: Kuwait Finance House. Australian Organisation for Quality. Web. <http://www.aoq.org.au/PDF/Saleh.pdf>. accesed at January $5^{\text {th }}, 2016$.

Salih, Y. et.al. (2014) Islamic marketing as a new marketing trend: an application for determining consumers' Islamic bank selection criteria. Banks and Bank Systems, Volume 9, Issue 1: 31-40.

Sameena, B. (2014). A Comparative Study of Customer Satisfaction of Islamic Banks and Conventional Banks in Oman The SIJ Transactions. Industrial, Financial \& Business Management (IFBM). Vol. 2 (4): 321-330.

Shahril, S. et.al. (2004). Adopting and Measuring Customer Service Quality in Islamic Banks: A Case Study of Bank Islam Malaysia Berhad. Journal of Muamalat and Islamic Finance Research Vol.1 (1): 41-50.

Shiraj, M. et.al. (2014). Comparative Study on Customer Satisfaction of Islamic and Conventional Banking in Sri Lanka. First International Symposium. FIA, South Eastern University of Sri Lanka SEUSL: 44-46.

Stewart, I. \& P. Fenn. (2006). Strategy: The Motivation for Innovation. Construction Innovation, Vol. 6 (3): 173-185.

Tang, K.H. \& M. Zairi. (1998). Benchmarking Quality Implementation in a Service Context: A Comparative Analysis of Financial Services and Institutions of Higher Education. Total Quality Management. Vol. 9: 407-420.

Tanjung, H. \& S. Bahri. (2005). Five Star Formulas in Developing Islamic Banking: A Case study from Indonesia. International Islamic University Islamabad. 23 Nov. 2005.

Wakhid, S. \& E. Soviyanti (2007). Adapting Islamic Banks Carter model: an Empirical Study in Riau Sharia banks Indonesia. Proceeding PESAT, Auditorium Kampus Gunadarma. 21-22 Aug.

Warsito, C. (2015). Image of Financial Institution as Islamic Bank in Mediation Service Quality and Customer Satisfaction on Customer Loyalty in Purworkto. Al-Iqtishad: Jurnal Ilmu Ekonomi Syariah (Journal of Islamic Economics). Vol. 7 (2): 217-228.

Wilson, Rodney. (2009). The Development of Islamic Finance in the GCC. Working paper. Kuwait Programme on Development, Governance and Globalisation in the Gulf States.

Zeithaml, et.al. (1996). Services Marketing. New York: McGraw-Hill. 